\title{
Literacies in a participatory, multimodal world: the arts and aesthetics of Web 2.0
}

\author{
Lalitha Vasudevan*
}

\begin{abstract}
In this article, a multimodal framework of literacies is engaged to call attention to the aesthetic aspects of adolescents' media making and identity explorations. Data from two studies are shared to offer complementary portraits of youth engaged with various technologies and media in two different out-ofschool settings. Both young men crafted forms of participation into their respective teaching and learning contexts through personal engagements with digital technologies that are becoming increasingly common features in adolescents' communicative landscapes. Meaning is found, therefore, in the nature of the young men's playful interactions with a variety of expressive modalities and not only in final compositions or texts.Recommendations to incorporate media play and personal explorations with technologies into language arts curricula are made in the conclusion.
\end{abstract}

Keywords: Multimodality. Adolescents. Media. Play. Aesthetics.

I am who I am not yet.

(Maxine Greene, 1996)

Sitting in front of a large Mac monitor, with his right hand on the mouse, twelve year-old TJ clicked through a variety of animation effects until he found one that applied a slow motion filter to the selected video clip. With another swift click of the mouse, TJ stretched a three-second clip into an eight-second rendition of his brother's flight through the air and ultimate fall from the playground's zip line. As he watched the clip repeatedly, TJ broke into fits of high pitched giggles that I had quickly come to love soon after I first met him over a year earlier. This was the first time that TJ had used iMovie, but not the first time using video editing software; that introduction occurred a month earlier as he experimented with

* Assistant Professor of Technology and Education at Teachers College, Columbia University. 
Windows MovieMaker while seated under a pavilion in the park, with my laptop on his lap. TJ had earned a reputation among our group of five middle grade boys for being a gifted multimedia storyteller. Over the course of the fifteen months we all met together, he produced several multimedia artifacts using photographs, video, and audio that we had created as a group. The clip of his little brother, which he edited with the "slo-mo" effect, found its way into a short, satirical piece entitled "Sibling Mutiny". TJ was an artful storyteller who also possessed a sharp wit, which was evident in his many compositions including a multimedia treatise on the educational possibilities of our group, precisely because we were located outside of school; a visual essay about the possible stories that different pieces of trash might hold; and the dialogic cacophony to be found in the spaces between teachers' words and the everyday social practices of youth.

The topic of teacher-student disjuncture echoed throughout many of the multimodal texts produced within the out-of-school storytelling project TJ was a part of, along with four of his peers. Chief among their ongoing reflective and multimodal analysis were their perceptions of how teachers viewed them and their practices, echoing the persistent tropes of risk embedded in schooling discourses (VASUDEVAN; CAMPANO, 2009). TJ, Cyrus, Romeo, Jamal, and Shawn wished to be "seen" for who they were or could be; these were narratives that were constantly animated in our group conversations that often held onto the possibility of the "not yet". After getting to know three of the boys when they were fifth graders, - TJ, Cyrus, and Romeo - I asked them to join me in creating this out-of-school space; soon, we were joined by Shawn, another student from their fifth grade class and Jamal, who was Romeo's brother. I was interested in how this group of boys, as individuals and as a group, would take up the invitation to compose stories using a variety of modalities for communication and expression (e. g., digital still cameras, video cameras, digital voice recorders). For fifteen months the six of us met to explore the literacies, aesthetics, and digital practices associated with telling stories across multiple modes (writing, image, sound, and gesture). In this study, I was inspired by the call to action articulated by the New London Group (1996) to expand conceptions of textual design to include literacies associated with more than the expressive modes of print-based reading and writing, typically privileged and evaluated in school. 
The disjuncture between the in-school and out-of-school lives of youth, resonant in the texts we created in our project, has been widely theorized and reported .(ALVERMANN; EAKLE, 2007; HULL; SCHULTZ, 2001; VASUDEVAN; WISSMAN, 2011). As youth are seeking new spaces for communication and composing, accessing a wide range of information sources, seeking and finding new audiences for their words and works, and forming new communities, relationships, and affiliations, their classroom experiences are becoming more constrained by the imposed rubrics of a high stakes testing climate. Whereas the curiosity of youth about the multiple affordances of new technologies is rich and varied, these same inclinations do not have a natural home in a context of measurement and accountability, where every activity is viewed through the prism of standards. Philosopher of education Maxine Greene, writing during a previous era of educational anxiety much like we are experiencing now, laments the lack of attention in the Goals 2000 legislation paid to the "untapped diversity among American youth today - its still undefined talents and energies, its differentiated modes of expression" (GREENE, 1995, p. 17).

Too often, the digital proclivities of youth are framed in the media and educational curricula through lenses of fear (e. g., cyberbullying), protectionism (e. g., internet predators), frivolity (e. g., social networking), or appropriation (e. g., uncritically assigning rap lyrics as the medium of math problem solving). How might teachers and our students, who are potentially teachers in their own right, "come to use imagination in a search for openings without which our lives narrow and our pathways become cul-de-sacs". (GREENE, 1995, p. 17). Against this backdrop of possibility and uncertainty, I invite readers to engage in studied (re) acquaintance with the emerging and evolving practice of language and literacies in a digitally mediated, participatory, and multimodal communicative landscape.

Communicative and expressive modalities, such as smart phones and video cameras, have become increasingly multifunctional and reflect an evolving digital landscape often referred to as Web 2.0. This term, Web 2.0, signals a shift in Internet capabilities and functionalities toward greater collaboration, participation, and distribution with respect to the production of knowledge, meaning, and attendant literacies. In this sense, "digital” signals technologies that facilitate the production, manipulation, and dissemination of communication signs and symbols. Social 
media is another term used to signal this new Internet ethos that builds from the technical affordances of Web 2.0 technologies and platforms, such as greater ease of participation, collaboration, and distribution. (KNOBEL; LANKSHEAR, 2007). It is important to note that whereas digital literacies are multimodal, literacy practices that are multimodal need not be digital (see for example, BOMER et al. this issue). Multitliteracies (NEW LONDON GROUP, 1996) was a term introduced to recognize global trends of increased linguistic and cultural diversity and the increased "complexity of texts with respect to nonlinguistic, multimodal forms of representation and communication, particularly, but not limited to, those affiliated with new technologies". (JEWITT, 2008, p. 245). With widespread social media use, particularly by youth, digitally mediated representation and communication are becoming increasingly diverse and more art-full. I propose that the "ethos" and "technical" affordances of Web 2.0 have the potential to catalyze the aesthetic creativity of youth.

Following a discussion of aesthetics in literacies, I explore the implications of participation in socially mediated communicative landscape for how we might rethink the nature of participation in classrooms. These new forms and spaces of participation are opening up opportunities for young people to assume new roles and perform new selves. Finally, I describe a stance that follows from the implications of broadened and reimagined understandings of participation and the performance of self: a renewed appreciation for progress and process in how we approach curriculum and pedagogy in language arts education, predicated upon the assumption that multimodal and multiliteracies work is a process that is perpetually in progress.

\section{An invitation to the aesthetic}

The literacies of children and youth in a Web 2.0 landscape are replete with acts of self-representation and expressive declarations. Evident in these works, accessible through online spaces such as YouTube and fanfiction sites, are the aesthetic inclinations of composing and authoring in a digital and multimodal landscape. By aesthetic inclinations, I am referring to the ways in which authors 
attend with care and intentionality to the design and composing processes of multimodal texts and communication, and to the ways that these texts communicate emotion, seek human connection, and embody an ethos usually evident in the arts. Imagination, both elusive and yet an utterly human capacity, renders our ability to connect with another's possible realities and to see meaning in the aesthetic constructions of those around us. It is this attention to the aesthetic that anchors my subsequent discussion of literacies in a social, digital world.

TJ's composing was an aesthetic response to his frustration at having to be the caretaker for his younger brother while he was meeting with our storytelling group. TJ's round face was bathed by the inviting glow of the monitor that he stared into with intensity as he reviewed and selected available images and video with care. Romeo, who had been using a digital video camera to record what happened during our meeting, had documented TJ's brother storming off, being retrieved by Jamal on his bike, and then returning to play on the gym equipment in the area of the park where we often gathered. By using these cultural artifacts captured by Romeo for a documentation purpose and manipulating them for new purposes, then combining them in new ways, TJ was engaging in the art of remixing; i.e., what Knobel and Lankshear describe as "the aesthetics, appreciation, form, and composition dimensions of remix practices" (LANKSHEAR, 2008, p. 26). He used the affordances of the video editing software, such as adding titles, to strategically create an interpretive frame around the video clips. Through the making of this authentic text, some of the frustration he had been carrying for two days was alleviated. Furthermore, this unexpected creation was the result of both personal motivation and playful experimentation that built on TJ's prior knowledge and success with video editing.

As suggested by TJ's experience, an invitation to the aesthetic also includes a recognition of play, a perspective that matches well with the ways emerging digital platforms encourage an ethos of experimentation. When conceived not merely as tools for computing, composing, or communication, but rather envisioned and used as spaces in which composing, self-representation, and participation takes place, Web 2.0 technologies can be more effectively leveraged in classrooms. Thus, if we attend meaningfully and playfully to aesthetics in language arts education then perhaps there will be greater inclination on the part of educators (and those 
to whom educators are accountable), to focus more on possibility and multiple modes of expression and less on uniformity of form and content.

The social media terrain is burgeoning as technologies are developed that are rapidly transforming many of the everyday practices of many youth. Their modes of communication, information access, and representation now routinely include the use of texting, instant messaging, microblogging (e. g., Twitter), blogging, creating social networking profiles, commenting on friends' online profiles, just to name a few of the ways that youth spend their time in online spaces (LENHART et al., 2008). This interpretation of the impact of social media on literacies framed by sociocultural theories that foreground the salience of sociocultural contexts for how literacy practices are engaged. Thus, literacies are understood to be social practices that are not decontextualized from the social and cultural spaces within which they are practiced. (STREET, 1995; LEWIS; ENCISO; MOJE, 2007). Portability of communication devices has perhaps complicated our notions of context (JACOBS, 2007; LEANDER; MCKIM, 2003), however the questions of "where", "how", "with whom" remain important factors that inform language and literacy practices.

My argument supports Jewitt's (2005) claim that literacies are "always multimodal", pointing out that even printed texts require attention to "visual marks, space, colour, font or style, and, increasingly image, and other modes of representation and communication" (p. 315). Additionally, I draw from emerging interdisciplinary studies and commentaries about social media and resulting cultural practices in a Web 2.0 world. (GREENHOW et al., 2009; ITO, 2010; LEWIS; FABOS, 2005; LIVINGSTONE, 2008). A common thread in these discourses focuses on the seamless and unencumbered incorporation of communicative modes by young people for a wide range of purposes. Jewitt (2008) and others (e. g., BEZEMER; KRESS, 2008; JEWITT; KRESS, 2003) underscore these findings in their ongoing theoretical project to decouple notions of literacy from the printed word alone. These scholars, writing out of the traditions of multimodality and semiotics, highlight the meanings held by all sign systems and symbols of which "letteracy" (LANKSHEAR; KNOBEL, 2007) - or the use of the alphanumeric code to produce written texts - is but one. Yet, the invitation to compose in image, using a variety of media (pastels, paints, crayons, markers, 
mixed media) and modes (the spoken word and dramatic performance), alongside the printed word is persistently missing in schools after early elementary grades.

Given the multitude of composing that happens multimodally, it is an educational disservice to relegate these elements of design and meaning making outside of the language arts domain to more specialized domains of arts classes, theater clubs, and the like. Although, even in the domain of arts education, the promise of exploration and the unexpected that the arts hold is diminishing as accountability measures dominate these spaces with increasing frequency (GADSDEN, 2008).

\section{Participation and the performance of multiple selves}

Children and youth today are "coming of age in a digital and globalizing world" and are poised to "develop and share new understandings of what it means to participate in relationships with others across social, geographic, and historical spaces". (STORNAIUOLO; HULL; NELSON, 2009, p. 383). Given this designation as "digital youth", they are positioned within globalizing discourses of competition, accountability, and achievement. But even as youth are players on a global stage with the potential attention of vast publics, their literacies, practices and compositions occur locally.

While TJ's multimedia experimentation described above occurred just prior to the widespread use of Web 2.0 technologies in youths' everyday social practices, the vignette demonstrates how he used video editing as a space in which to make his feelings heard. But TJ was not alone in this endeavor. If we widen the lens on the opening scene, we would see that TJ's composing took place with occasional input from Cyrus, Romeo, and Jamal who were also present for that day's meeting. Jamal, who was the ultimate hero of the day when TJ's brother ran off, contributed his opinions about the inclusion of sound effects (which were ultimately taken out) and the overall narrative structure. As TJ maintained control of the mouse with his right hand, Jamal had pulled another chair close to the editing station and begin to gesture toward the screen with his left hand. For several minutes, TJ and Jamal functioned like a singular unit with $\mathrm{TJ}$ executing commands that Jamal 
called out. These were unusual roles for both TJ and Jamal to assume since both had largely remained on the artifact production side of our group composing contributing rolls of film, audio recordings, images culled from Internet searches, and favorite music selections to the archive from which we all drew for our own text productions. Participation amongst the six of us varied in form and content, but did not diminish the quality of citizenship. In fact, the ability to participate in myriad ways augmented a sense of belonging and ownership within the storytelling community we had formed.

Hull, Stornaiuolo, and Sahni (in press) draw on conceptualizations of cosmopolitanism (APPIAH, 2006; HANSEN, 2010) to articulate how youth and teachers involved in an online social networking space (Kidnet) can come to exhibit cosmopolitan dispositions toward one another. These dispositions are characterized by the ways that both groups are "receptive to the new and yet not in a way that abandons or negates the local". (HANSEN, 2010, p. 15, cited in HULL; STORNAIUOLO; SAHNI, in press). They offer one orientation toward participation that harnesses the significance of citizenship and opportunities for participation that are actively pursued through the practices, interactions, and understandings inspired by engagement with and within Kidnet. By composing and ultimately sharing multimodal artifacts constructed to communicate something about themselves, the young women that the authors describe are using the "self" as a text through which to examine their relationship to their community, social norms, institutions.

A renewed ethos of citizenship is what Black (2005) has described in her work with ELLs and the linguistic solace they find in fan fiction sites. They seemingly seek and find linguistic refuge and cultivate meaningful citizenship through their participation in these spaces in ways they could not find in classrooms. The girls whose practices Black studied and the fan fiction community members with whom they exchanged stories is similar to being engaged in a deliberative openness (HANSEN, 2009) with one another. In a space where such a view of participation was practiced, the grammatical stumbling blocks that precluded the girls' classroom participation and recognition were not used to automatically exclude them from the fan fiction community. Rather the aesthetic value of their remixed narratives using characters from popular media was valued. 
Jenkins and colleagues (2006) articulate the contours of the increasingly participatory cultures with which youth are involved. They define participatory cultures, which are mediated by social media technologies and platforms, as "relatively low barriers to artistic expression and civic engagement, strong support for creating and sharing one's creations, and some type of informal mentorship whereby what is known by the most experienced is passed along to novices" ( $p$. 3). Amidst this cultural shift, however, is what the authors term the "participation gap", or the unequal access to understandings about and opportunities to more fully participate in the spaces, conversations, and practices that social media present. That is, whereas many youth are finding ways into and onto the new digital landscapes, only some are adequately being supported in their schooling experiences to cultivate these digital imaginations.

As shown with the creation of "Sibling Mutiny", composing can be participatory and shared in a very physical sense and allow collective pooling of artifact and narrative resources to construct new kinds of texts. Communication and composing devices are becoming more portable and multifunctional - such as smart phones, digital cameras, digital voice recorders, tablets, netbooks - and they allow for greater inclusion of youths' non-school lives in classroom projects and conversations. For example, I was motivated to design a digital media course for older youth, who were enrolled in an alternative to incarceration program, because of the many ways social media encourage the use of multiple funds of knowledge. In this course, I sought to provide opportunities for young adults to bring in their cultural resources and narrative histories in the creation of multimedia texts on topics of their choosing. We met twice a week for two-hour sessions over a period of ten weeks. Leonard was one of eight young men who enrolled in the course, all of whom had experienced early involvement with incarceration and detention.

For the first three weeks of the class, Leonard was stuck without an idea for his project. Each session, he would sit in the same seat, place his pristine Detroit Tigers cap on the table next to the laptop he was using, open up iMovie, and tap his bright white sneakers together while listening to music. Attempts to spark ideas - including narrative brainstorming, taking the digital camera to photograph locations and people who held meaning for him, a discussion about preferences in music and other popular media - did not initially yield a topic that he could 
effectively build upon. One afternoon, while conducting Internet searches for "random images" Leonard found his inspiration in the image of a courthouse. He began talking in an uncharacteristically rapid fashion and he sketched out a storyboard and started to narrate the elements to include in his project. Leonard's project was a music video for his brother's song, "It's Alright", a meditation on a moment of peace in their family after a series of significant life challenges, including incarceration and severe illness. Using a digital still camera and camera phone (both equipped with video capture capability), Leonard collected all of the video and stills for his highly personal narrative that was also punctuated with images found using Internet searches and others that were imported from his and his siblings' MySpace profiles. By remixing these various artifacts for a new purpose - a music video - Leonard contributed his voice to the serious issues explored by his peers, including community policing, sentencing policies, and juvenile arrests while managing to convey an aesthetic of family, hope, and love. As with similar out-of school projects (c. f. HULL; STORNAIUOLO; SAHNI, in press), Leonard's self-exploration contained profound acts of analysis and reflection, suggesting that opportunities for this form of reflective composing are themselves educational pursuits.

For young people who are routinely positioned as lacking civic engagement, being outside of social norms, or simply labeled "at risk", having opportunities to enter meaningfully into the classroom discourse through their arts and language proved to be significant. The new affordances of technologies and social media platforms promote the inclusion of youths' literate identities from across contexts by virtue of their mere existence. In other words, a classroom space in which social media and technologies are not feared or dismissed, but rather included with the promise of building on youths' familiarity with them can be the very thing that shifts a classroom spirit from inhospitable to inviting.

We need to rethink language arts education by first recognizing technologies as composing spaces, while also acknowledging the complexity of navigating these spaces with youth who both know a great deal about 2.0 technologies and have become familiar with the new literacies that these technologies inspire. Such a posture invites recognition of the various authorial stances (VASUDEVAN; SCHULTZ; BATEMAN 2010, under review) that children and youth assume in 
embodied and performative ways. Web 2.0 technologies can amplify educators' ability to build on what we know about the storied lives and playful tendencies of children's imaginations provided that we "recognize that children's identities who they imagine themselves to be and who they imagine they could become - are inextricably bound with learning”. (STORNAIUOLO; HULL; NELSON, 2009, p. 384).

\title{
Process and progress: teaching for openings ${ }^{1}$
}

\author{
"The possible's slow fuse is lit \\ by the imagination." \\ (Emily Dickinson, 1914)
}

With all of this composing, communicating, and representing, one might ask: where does all this stuff end up in a seemingly infinite world of online sites? Is it of value to anyone? Certainly educators and composers alike want to know what becomes of the material digital artifacts that are created. However, the question also suggests a concern about the influence on and traces of the composing process in the composer. We can imagine the "digital afterlife" (SOEP; CHÁVEZ, 2010) of texts once they are designed, composed, produced, disseminated, and interpreted. Videos on YouTube, comments made on blogs, and most recently the announcement that tweets will be archived by the Library of Congress cement our understandings that these are texts that are present not only in the current moment, but will continue to be present in the ways they are referenced in other productions, remixed for new purposes, excerpted, re-vocalized, and reinterpreted in new contexts by others. In a different sense, the narrative residue remains in the embodied memories for the composer and is reconstituted in subsequent narratives and acts of participation and citizenship in newly formed communities

1 This subheading comes from the title of Chapter 9 in Greene's (1995) collection of essays, Releasing the Imagination: Essays on Education, the Arts, and Social Change. Greene's persistent faith in teachers is echoed through this volume, but especially in this chapter where she calls on educators to view literacy as a "social undertaking" that must be "sought in pluralist classrooms" where "there will be a play of differences, inevitably, through which meanings can emerge" (p. 121). 
and affiliations. The aesthetic of Web 2.0 is quintessentially "not yet", where the self - and its textual and multimodal manifestations - are truly in process.

In her rich descriptions of children's storytelling and play, Paley $(1986 ; 2004)$ writes convincingly and compelling about the educational possibilities that are opened up when children are given the space to fully explore their fantastical imaginations. For TJ and Leonard and countless other children and youth, these imaginations are finding homes across digital and digitally mediated social spaces. We have ample evidence to recognize that the literate self implies "a familiarity with the full range of communicative tools, modes, and media, plus an awareness of and a sensitivity to the power and importance of representation of self and others" (HULL, 2003, p. 230); and an ability to "to use the dominant symbol systems of the culture for personal, aesthetic, cultural, social, and political goals". (HOBBS; JENSEN, 2009, p. 4-5). Do we have the educational spaces to foster these literate selves? How might we read and write and teach for openings and also maintain the integrity of our convictions? The invitation to reconsider the aesthetics of language arts education, as inspired by the emerging Web 2.0 landscape, does not imply a total dismissal of all prior practice. Rather, as I have argued here, the established tenets of play, imagination, and possibility that have long been advocated for by philosophers of education, teachers, researchers, and youth themselves, gain traction with increasing digital capabilities. The deep chasm that is growing between young people's in-school and out-of-school experiences amplifies the urgency for incorporating an aesthetic stance in literacy studies and language arts education, particularly as the arts are slowly being pushed out of the commitments schools make to children. Such a reality is especially unsettling at a time when there are virtually countless spaces and artifacts available for the creative impetus to be cultivated and thoughtfully nurtured. Teachers have an opportunity to engage in the pursuit of the imagination with the children and youth who sit with them in classrooms, to learn, play, and imagine together.

Such a stance is also cognizant of the portability of technologies and the ways platforms for production and distribution and social networking capabilities encourage the circulation of literacies. Many scholars have aptly called attention to the increasingly constrained conditions that teachers face daily - precipitated in large part by the demands of high stakes testing and federally and state mandated 
measures of accountability. If "place, spaces, and landscape play a role in affording and constructing, constraining and directing, the dreams and practices of youth" (STORNAIUOLO; HULL; NELSON, 2009, p. 388), what do current classroom configurations indicate about their ability to nurture the "dreams and practices of youth"?

The field of education will likely continue to wrestle with whether and how "broad forms of semiotic mediation" might be made to count as literacy. (LEANDER; MCKIM, 2003, p. 225; see also GALLEGO; HOLLINGSWORTH, 2000). At a time when new technologies demand that we reconceptualize our basic notions of communication (KRESS, 2003) and the very concept of educational "basics" (STORNAIUOLO; HULL; NELSON, 2009), teachers are challenged to ask what the purposes of language arts education should be. Even though most classrooms are overwhelmingly governed by policies that restrict students' new literacies knowledge they can pursue a pedagogy of the "not yet" told, invented, and communicated.

\title{
Letramentos em um mundo participativo e multimodal: as artes e a estética da web $\mathbf{2 . 0}$
}

\begin{abstract}
Resumo
Neste artigo, uma estrutura multimodal de letramentos é abordada com o objetivo de chamar a atenção para os aspectos estéticos da criação de mídia de adolescentes e de suas explorações identitárias. Dados de dois estudos são compartilhados para oferecer retratos complementares de adolescentes envolvidos com várias tecnologias e meios em dois ambientes distintos fora da escola. Ambos os jovens criaram formas de participação em seus respectivos contextos de ensino e aprendizado por participações pessoais com tecnologias digitais que estão se tornando cada vez mais comuns nos ambientes comunicativos de adolescentes. O significado é encontrado, portanto, na natureza das interações lúdicas dos jovens com várias modalidades expressivas e não somente nas composições ou textos finais. Recomendações de se incorporar interpretações com mídias e explorações pessoais com tecnologias em currículos de artes linguísticas são feitas na conclusão.
\end{abstract}

Palavras-chave: Multimodalidade. Adolescentes. Mídia. Interpretação. Estética. 


\title{
Littéracie dans un monde participatif et multimodal: l'art et l'esthétique du Web 2.0
}

\begin{abstract}
Résumé
Dans cet article, on a ressource à un groupe multimodal de littéracies dans le but d'attirer l'attention aux différents aspects de la mise en place des médias pour adolescents et leur exploration d'identité. Des données de deux études sont partagées pour offrir des portraits complémentaires des jeunes engagés dans différents technologies et médias en deux différents contexts pas liés à l'école. Les jeunes ont bâti des formes de participation dans leur contextes d'enseignement et apprentissage au travers des engagements personnels avec des technologies numériques que deviennent des charactéristiques de plus en plus courantes dans le paysage de la communication des adolescents. On a pourtant trouvé du sens dans la nature des intéractions ludiques des jeunes avec une variété de modalités expréssives et non pas seulement dans des compositions ou textes finaux. À guise de conclusion, on donne des récommendations pour l'introduction du « media play » et des explorations personnelles avec des technologies dans les programmes des arts.

Mots-clés : Multimodalité. Adolescents. Médias. Interprétation. Esthétique.
\end{abstract}

References

ALVERMANN, Donna E.; EAKLE, Jonathan. Dissolving learning boundaries: The doing, re-doing, and undoing of school. In: THIESSEN, Dennis; COOKSATHER, Alison (Ed.). International handbook of student experience in elementary and secondary school. Dordrecht, The Netherlands: Springer, 2007. p. 143-166.

APPIAH, Anthony. Cosmopolitanism: ethics in a world of strangers. London: Allen Lane, 2006.

BEZEMER, Jeff; KRESS, Gunther. Writing in multimodal texts: A social semiotic account of designs for learning. Written communication, v. 25, n. 2, p. 166-195, 2008 .

BLACK, Rebecca W. Access and affiliation: The literacy and composition 
practices of English-language learners in an online fanfiction community. Journal of adolescent and adult literacy, v. 49, n. 2, p. 118-128, 2005.

GADSDEN, Vivian L. The Arts and Education: Knowledge Generation, Pedagogy, and the Discourse of Learning. Review of research in education, v. 32, n. 1, p. 29-61, 2008.

GALLEGO, Margaret A.; HOLLINGSWORTH, Sandra. What counts as literacy: challenging the school standard. New York: Teachers College Press, 2000.

GREENE, Maxine. Releasing the imagination: essays on education, the arts, and social change. San Francisco, CA: Jossey-Bass, 1995.

GREENHOW, Christine; ROBELIA, Beth; HUGHES, Joan E. Learning, Teaching, and Scholarship in a Digital Age: Web 2.0 and Classroom Research: What Path Should We Take Now?. Educational researcher, v. 38, n. 4, p. 246-259, 2009.

HANSEN, David T. Chasing butterflies without a net: Interpreting cosmopolitanism. Studies in philosophy and education, v. 29, n. 2, p. 151-166, 2009.

HANSEN, David T. Cosmopolitanism and education: A view from the ground. Teachers college record, v. 112, n. 1, p. 1-30, 2010.

HOBBS, Renee; JENSEN, Amy. The past, present, and future of media literacy education. Journal of media literacy education, v. 1, p. 1-11, 2009.

HULL, Glynda A. At last: Youth culture and digital media: New literacies for new times. Research in the teaching of english, v. 38, n. 2, p. 229-233, 2003.

HULL, Glynda A.; SCHULTZ, Katherine. Literacy and learning out of school: A review of theory and research. Review of educational research, v. 71, n. 4, p. 575-611, 2001.

HULL, Glynda A.; STORNAIUOLO, Amy; SAHNI, Urvashi. Cosmopolitan imaginings of self and other: global youth communicate online. English Education. In press.

ITO, Mizuko et al. Hanging out, messing around, and geeking out: kids living and learning with new media. Cambridge, Mass.: MIT Press, 2010.

JACOBS, Gloria. Locating the local: developing methodology for problematizing the Construction of Context. In: BLACKBURN, Mollie V.; CLARK, Caroline T. (Ed.). Literacy research for political action and social change. New York: Peter Lang, 2007. p. 53-75.

JENKINS, Henry et al. Confronting the challenges of participatory culture: media education for the 21st century. Chicago, IL: The MacArthur Foundation, 
2006.

JEWITT, Carey. Multimodality, "Reading", and "Writing" for the 21st Century. Discourse: studies in the cultural politics of education, v. 26, n. 3, p. 315-331, 2005.

JEWITT, Carey. Multimodality and Literacy in School Classrooms. Review of research in education, v. 32, n. 1, p. 241-267, 2008.

JEWITT, Carey; KRESS, Gunther R. Multimodal literacy. New York: P. Lang, 2003.

KNOBEL, Michele; LANKSHEAR, Colin. A new literacies sampler. New York: KNOBEL, Michele; LANKSHEAR, Colin. Remix: The art and craft of endless hybridization. Journal of adolescent \& adult literacy, v. 52, n. 1, p. 22-33, 2008.

KRESS, Gunther. Literacy in the new media age. London: Routledge, 2003.

LANKSHEAR, Colin; KNOBEL, Michele. Sampling "the new" in new literacies. In: KNOBEL, Michele; LANKSHEAR, Colin (Ed.). A new literacies sampler. New York: Peter Lang, 2007. p. 1-24.

LEANDER, Kevin M.; MCKIM, Kelly K. Tracing the everyday "sitings" of adolescents on the Internet: A strategic adaptation of ethnography across online and offline spaces. Education, communication \& information, v. 3, n. 2, p. 211240, 2003.

LENHART, Amanda; ARAFEH, Sousan; SMITH, Aaron; MACGILL, Alexandra Rankin. Writing, technology, and teens. Washington, DC: Pew Charitable Trusts, 2008. Retrieved March 29, 2010, from: <http://pewinternet.org/pdfs/PIP Writing_Report_FINAL3.pdf>.

LEWIS, Cynthia; ENCISO, Patricia E.; MOJE, Elizabeth Birr. Reframing sociocultural research on literacy: Identity, agency, and power. Mahwah, N.J.: Lawrence Erlbaum Associates, 2007.

LEWIS, Cynthia; FABOS, Bettina. Instant messaging, literacies, and social identities. Reading research quarterly, v. 40, n. 4, p. 470-501, 2005.

LIVINGSTONE, Sonia. Taking risky opportunities in youthful content creation: teenagers' use of social networking sites for intimacy, privacy and self-expression. New media \& society, v. 10, n. 3, p. 393-411, 2008.

NEW LONDON GROUP. A pedagogy of multiliteracies: Designing social futures. Harvard Educational Review, v. 66, n. 1, p. 60-93, 1996. 
PALEY, Vivian Gussin. On listening to what the children say. Harvard educational review. v. 56, n. 2, p. 122-131, 1986.

PALEY, Vivian Gussin. A child's work: the importance of fantasy play. Chicago: University of Chicago Press, 2004.

SOEP, Elisabeth; CHÁVEZ, Vivian. Drop that knowledge: youth radio stories. Berkeley, CA: University of California Press, 2010.

STREET, Brian V. Social literacies: critical approaches to literacy in development, ethnography, and education. New York: Longman, 1995.

STORNAIUOLO, Amy; HULL, Glynda; NELSON, Mark Evan. Mobile texts and migrant audiences: Rethinking literacy and assessment in a new media age. Language arts, v. 86, n. 5, p. 382-392, 2009.

VASUDEVAN, Lalitha; CAMPANO, Gerald. The social production of adolescent risk and the promise of adolescent literacies. Review of research in education, v. 33, p. 310-353, 2009.

VASUDEVAN, Lalitha; SCHULTZ, Katherine; BATEMAN, Jennifer. Rethinking composing in a digital age: authoring literate identities through multimodal storytelling. Written communication, v. 27, n. 4, p. 442-468, 2010.

VASUDEVAN, Lalitha; WISSMAN, Kelly. Out-of-school literacy contexts. In: LAPP, Diane; FISHER, Douglas (Ed.). Handbook of research on teaching the english language arts. 3rd ed. New York: Lawrence Erlbaum Associates, 2011. 
